Fastabiq: Jurnal Studi Islam

ISSN 2723-0228

Volume 1 Nomor 2 Nopember 2020

Halaman 132-144

\title{
ANALISIS SUBSTANSI MATA KULIAH WAJIB UMUM \\ PENDIDIKAN AGAMA DALAM KERANGKA GENERAL EDUCATION
}

\author{
Silmi Kapatan Inda Robby \\ Politeknik Al Islam Bandung \\ silmi@politeknikalislam.ac.id
}

\begin{abstract}
This research is motivated by the dynamics that occur in policy changes and the implementation of religious education MKWU lectures that are not taken seriously. This study focuses on the study of the substance of the general compulsory religious education subject within the framework of general education. The method used is literature study. The results of this study indicate that the substance of the general compulsory subject of religious education within the framework of general education at the conceptual level must be religious education, not only as a transfer of knowledge about religious teachings, namely education that does not only touch cognitive aspects, but education that can penetrate the hearts and inner consciousness of students.
\end{abstract}

Keywords: Substansi; Mata Kuliah Wajib Umum; Pendidikan Agama; General Education

\begin{abstract}
Abstrak
Penelitian ini dilatarbelakangi oleh adanya dinamika yang terjadi dalam perubahan kebijakan dan penyelenggaraan perkuliahan MKWU pendidikan agama yang kurang ditangani secara serius. Penelitian ini berfokus pada kajian substansi mata kuliah wajib umum pendidikan agama dalam kerangka general education. Metode yang digunakan adalah studi kepustakaan. Hasil penelitian ini menunjukkan bahwa substansi mata kuliah wajib umum pendidikan agama dalam kerangka general education pada tataran konseptual haruslah merupakan pendidikan yang religius, tidak hanya sebatas pengalihan pengetahuan (transfer knowledge) tentang ajaran-ajaran agama, yaitu pendidikan yang tidak sekedar menyentuh aspek kognitif, tetapi pendidikan yang dapat menembus hati dan kesadaran batin mahasiswa.
\end{abstract}

Kata Kunci: Substansi; Mata Kuliah Wajib Umum; Pendidikan Agama; General Education 


\section{PENDAHULUAN}

Kebijakan Mata Kuliah Wajib Umum Agama Islam pada perguruan tinggi umum mengalami dinamika dan tantangan yang beragam. Secara historis dapat diamati pada tahun $1962^{1}$ (masa Orde Lama), perkuliahan Agama (Islam) merupakan mata kuliah umum yang bersifat pilihan dan anjuran, sehingga tidak mengikat pada setiap mahasiswa untuk mengambilnya. Ketika masa Orde Baru, posisi perkuliahan Agama (Islam) mendapat penguatan. Hal tersebut ditandai dengan penetapan mata kuliah Agama (Islam) sebagai mata kuliah wajib yang ditawarkan kepada setiap mahasiswa dan pengelolaannya dilakukan secara kelembagaan melaui suatu biro khusus yang menyatu dengan mata kuliah wajib lainnya, yaitu: Pendidikan Pancasila, Pendidikan Kewiraan, Pendidikan Kewarganegaraan, Pendidikan Bahasa Indonesia dan yang lainnya. ${ }^{2}$

Tahun 1983, berdasarkan Surat Keputusan Direktorat Jenderal Pendidikan Tinggi (Ditjen Dikti) menetapkan Kurikulum Inti Mata Kuliah Dasar Umum, yang di dalamnya terdapat mata kuliah Agama (Islam). ${ }^{3}$ Selain itu, pengelolaannya pun mengalami perubahan, yang semula di bawah biro lalu dialihkan ke Jurusan Mata Kuliah Dasar Umum (MKDU) pada fakultas yang paling dekat rumpun dan bidang keilmuannya. Terkait dengan penamaan MKDU tentu memiliki landasan filosofis yang lugas, karena setiap mata kuliah yang tergabung di dalamnya merupakan dasar dan asas yang menyajikan landasan spiritual keagamaan, moral, kebangsaan, nasionalisme, dan sosial budaya dalam pengembangan bidang kelimuan dan keahlian setiap individu mahasiswa. Pada jenjang perguruan tinggi, untuk mengembangkan manusia seutuhnya, diupayakan melalui tiga kelompok mata kuliah, yaitu Mata Kuliah Dasar Umum (MKDU), Mata Kuliah Dasar Keahlian (MKDK), Mata Kuliah Keahlian (MKK), yang sesuai dengan kebutuhan serta tujuan perguruan tinggi yang bersangkutan. ${ }^{4}$

Pada tahun 1990, nama MKDU mengalami perubahan menjadi Mata Kuliah Umum (MKU), dan pada Tahun 2000 berubah lagi menjadi Mata Kuliah Pengembangan Kepribadian (MPK). Perubahan pada penamaan rumpun mata kuliah berimplikasi pula dengan perubahan kelembagaan dan pengelolaan. Rumpun MKDU sebelumnya berkedudukan setingkat jurusan (Jurusan MKDU), maka pengelolaan MKDU berikutnya diamanatkan pada sebuah Unit Pelaksana Teknis Mata Kuliah Umum (UPT-MKU) yang secara hierarkis berada di bawah koordinasi langsung Pembantu Rektor I Bidang Akademik. ${ }^{5}$

Tahun 2006, Direktorat Jenderal Pendidikan Tinggi mengeluarkan keputusan tentang Ramburambu Pelaksanaan Kelompok Matakuliah Pengembangan Keprbadian di Perguruan Tinggi. Surat Keputusan Dirjen Dikti ini menindakalanjuti ketentuan dalam Undang-Undang Sistem Pendidikan Nasional Tahun 2003, yang menentukan kurikulum pendidikan tinggi wajib memuat Pendidikan Agama, Pendidikan Kewarganegaraan, dan Bahasa. ${ }^{6}$ 
Beberapa perubahan dalam hal penamaan yang semula MKDU mejadi MKU dan MPK menunjukkan bahwa eksistensi kelembagaan kelompok mata kuliah wajib ini mengalami dinamika. Sehingga, dalam implementasinya memunculkan kesan hanya sekedar memenuhi tuntutan undangundang dan peraturan yang berlaku. Implikasinya, terdapat persepsi pada sebagian mahasiswa, dosen, program studi, unsur pimpinan perguruan tinggi yang memberikan pandangan bahwa mata kuliah wajib ini hanya sebagai pelengkap kurikulum. ${ }^{7}$

Merujuk pada Undang-Undang Nomor 12 Tahun 2012 tentang Pendidikan Tinggi, penamaan MPK berubah dengan menambahkan kata wajib menjadi Mata Kuliah Wajib Umum (MKWU). Harapannya, dengan perubahan nama ini dapat mengembalikan peran dan fungsi MKWU sebagai kelompok mata kuliah yang menjadi core value dan memberikan landasan dasar untuk pengembangan kepribadian mahasiswa juga pengembangan bidang keilmuan dan keahlian masingmasing. ${ }^{8}$

Perubahan kebijakan yang memuat nomenklatur rumpun mata kuliah wajib umum, Pendidikan Agama Islam—sebagai salah satu bagian dari mata kuliah Pendidikan Agama-yang diikuti pula dengan perubahan Standar Isi menarik untuk dikaji dan dianalisis secara lebih mendalam menggunakan kerangka general education. Hal ini didasari oleh pertimbangan bahwa penggunaan kata umum selalu melekat pada rumpun atau kelompok mata kuliah ini dari awal perumusan sampai kebijakan yang terbaru.

Layanan program studi pada perguruan tinggi pada umumnya sangat fokus terhadap penyelenggaraan mata kuliah selain MKWU, karena mata kuliah selain MKWU dipandang benarbenar mata kuliah yang terkait langsung dengan kepentingan program studi tersebut dalam menunjang kompetensi lulusan dari program studi perguruan tingginya. Sebaliknya, MKWU dipandang bukan milik program studi dan/atau perguruan tingginya melainkan "milik negara". Implikasinya penyelenggaraan MKWU pada banyak program studi perguruan tinggi, sering terabaikan. $^{9}$

Data menunjukkan bahwa penyelenggaraan mata kuliah umum tidak ditangani secara serius. Beberapa indikasi untuk memperkuat pernyataan ini, antara lain, dosen pengampunya bukan orang yang berkompeten dalam bidangnya atau tidak memiliki background akademik yang linier atau tidak pernah mengikuti diklat untuk mengampu mata kuliah tersebut, diselenggarakan dalam kelas-kelas besar, dan lebih dari itu lembaga pengelolanya tidak memiliki concern yang kuat dan/atau tidak memiliki otoritas yang memadai untuk mengelola MKWU secara efektif. Implikasinya, MKWU terkesan bagaikan mata kuliah yang tidak bertuan. Kurang bijak tampaknya, apabila bangsa ini berharap banyak terhadap output pelaksanaan MKWU ini. ${ }^{10}$

Selain itu, Pendidikan agama (Islam) dalam Sistem Pendidikan Nasional, secara eksistensial merupakan bagian dari general education yang misinya adalah membina karakter peserta didik 
melalui berbagai pembinaan moral dan transfer nilai-nilai kebaikan, baik bagi kehidupan individual atau dalam kehidupan bersama. Uraian tersebut memunculkan suatu pertanyaan, bagaimana pendidikan agama dalam membina religiusitas? Bagaimana pendidikan agama dalam kerangka general education?

\section{METODE PENELITIAN}

Penelitian ini merupakan penelitian kualitatif sesuai dengan objek penelitiannya, yaitu berupaya mengumpulkan, mengolah, dan menganalisis data secara kualitatif dan mendefinisikannya secara kualitatif (Bachtiar, 1997). Mengacu pada sifat longgar penelitian kualitatif terhadap instrumen pengumpulan data, karena lebih menitikberatkan pada proses daripada produk suatu objek penelitian (Muhadjir, 2000: 43), dalam penelitian ini penulis mengikuti pendapat Bogdan dan Taylor (1975) dengan melakukan studi pustaka.

Data yang digunakan dalam penelitian ini seluruhnya bersumber dari bahan pustaka. Pengumpulan data dilakukan melalui tinjauan pustaka yang relevan dengan topik yang sedang dibahas. Sumber data antara lain: buku literatur, dokumen peraturan, jurnal, dan website yang memuat berbagai informasi yang dibutuhkan. Data yang terkumpul selanjutnya dibagi-bagi menurut jenisnya untuk persiapan analisis lebih lanjut.

Setelah data terkumpul, kemudian dianalisis dengan menggunakan teknik analisis isi (content analysis) yaitu kajian teks yang cermat dan sistematis berdasarkan kondisi-sebagaimana dikemukakan oleh Muhadjir (2000). Dalam proses analisis data, berbagai logika induktif dan deduktif digunakan, sebagaimana yang sesuai dalam penelitian kualitatif pada umumnya.

\section{PEMBAHASAN}

\section{Pendidikan Agama dalam Membina Religiusitas}

Dalam Undang-Undang Nomor 20 Tahun 2003 tentang Sistem Pendidikan Nasional yang digunakan sebagai dasar penyelenggaraan pendidikan nasional, disebutkan bahwa, Pendidikan agama dimaksudkan untuk membentuk peserta didik menjadi manusia beriman dan bertakawa kepada Tuhan Yang Maha Esa serta berakhlak mulia. Selain itu, dinyatakan pula bahwa Kurikulum Pendidikan Tinggi wajib memuat Pendidikan Agama. ${ }^{11}$

Joachim Wach (1984: 59) menyebutkan bahwa tesis filosofis tentang manusia adalah homo religiousus, yang berarti bahwa manusia merupakan makhluk yang sadar terhadap ketuhanan. ${ }^{12}$ Dalam batiniahnya, kesadaran ketuhanan ini akan selalu muncul dalam berbagai bentuk ekspresi, yang tidak dapat dihilangkan. Bagi manusia, beragama itu fitrah yang perlu disalurkan. Muthahhari (1984: 43-44) menjelaskan, agama adalah satu-satunya wadah yang tepat untuk menyalurkan fitrah keberagamaan ini. ${ }^{13}$ Ketiadaan agama pada diri membuat fitrah keberagamaan akan tumbuh liar dan 
destruktif. Dengan demikian, pendidikan agama merupakan suatu hal yang berhubungan dan terkait langsung dalam membina suatu dimensi dari kemanusiaan.

Pada sisi yang lain, M. I. Soelaeman (1988: 43-44) menyatakan bahwa manusia merupakan makhluk yang belum selesai sebagai manusia sewaktu ia dilahirkan. Untuk memungkinkannya dapat hidup dan bertahan sebagai manusia serta dapat melaksanakan tugas hidup kemanusiaannya, ia perlu dididik dan dibina oleh manusia dalam lingkungan kemanusiaan. Dengan ketiadaan pendidikan, potensi manusia akan tumbuh kerdil dan tanpa arah. ${ }^{14}$ Dengan demikian, pendidikan merupakan kebutuhan bagi manusia, H. M. Said (1989: 19) menyebutkan bahwa, manusia adalah homo educandum et educabile, manusia itu dapat dididik dan memerlukan pendidikan. ${ }^{15}$

Ikhtiar untuk membina pribadi yang religius diperlukan adanya upaya pendidikan. Pendidikan yang berkaitan langsung dengan tujuan membina pribadi yang religius adalah pendidikan agama. Melalui pendidikan agama, pribadi itu akan dapat dibina menjadi individu yang religius, dapat dibantu kedewasaan agamanya, dan dapat dikembangkan dan diarahkan potensi keragamaannya. Atas dasar itu maka pendidikan agama merupakan suatu keharusan adanya dalam suatu sistem pendidikan.

Dalam upaya untuk mencapai tujuan membina manusia yang religius, tentu konsep pendidikan agama yang tepat untuk diterapkan. Terkait dengan pendidikan religius ini, M. D. Dahlan (1988:15) mengemukakan, pendidikan yang religius adalah pendidikan yang bukan sekedar pendidikan tentang religi yang hanya bergerak pada domain kognitif dan tidak sempat meresap pada bidang afektif. ${ }^{16}$ Pernyataan ini memberikan makna bahwa, pendidikan agama haruslah diarahkan pada pembinaan domain afektif, menjadikan individu yang dididik mampu menginternalisasikan nilainilai agama dan menghayati ruh kandungan dalam ajaran agama, sehingga menimbulkan daya gerak dalam dirinya untuk mengaplikasikan dalam amaliah berupa wujud tindakan dan perilaku yang nyata.

Pendidikan agama (yang religius) berupa pengetahuan dan pemahaman ajaran agama serta nilai-nilai agama (domain kognitif) bukan tujuan, melainkan alat atau media pendidikan untuk mencapai tujuan. Sebagai contoh, pengetahuan tentang bahwa shalat itu wajib dalam agama Islam adalah sekedar pengetahuan atau media, agar timbul keterikatan yang kuat pada individu tentang harusnya ia melaksanakan shalat dan sama sekali tidak boleh meninggalkannya. W. Temple (dalam Rasjidi, 1972:14) mengatakan, pokok dari agama bukan hanya sebatas pengetahuan tentang Tuhan, akan tetapi perhubungan antara seseorang manusia dengan Tuhan. ${ }^{17}$

Pendidikan agama dapat dimaknai sebagai upaya menuntun individu yang dididik dalam menginternalisasikan nilai-nilai agama dan ruh-ruh keagamaan serta membimbing cara merealisasikannya dalam bentuk tindakan nyata. Secara ringkasa dapat dikatakan, upaya menjadikan individu merasa terikat pada nilai-nilai ajaran agama. ${ }^{18}$ 
Pada sisi yang lain, pendidikan agama bagi kehidupan manusia dapat dipandang sebagai proses menghubungkan koneksi kebutuhan asasi manusia yaitu penyaluran fitrah beragama dengan sarana yang mampu memenuhi kebutuhan tersebut yaitu agama, sehingga potensi itu dapat tersalurkan dan dikembangkan secara teratur dan sistematis sehingga mencapai kepuasan batiniah yang hakiki.

\section{Konsep Dasar General Education}

General education atau dalam bahasa Indonesia disebut sebagai pendidikan umum merupakan suatu istilah yang mulai diperkenalkan di Amerika Serikat pada abad kesembilan belas dan lebih berkembang setelah memasuki abad kedua puluh. ${ }^{19}$ Munculnya istilah program General Education berkaitan erat dengan kecenderungan perkembangan dalam dunia pendidikan dan pengajaran serta perkembangan kehidupan masyarakat sendiri.

Gerakan dalam dunia pendidikan yang mempunyai nama General Education berusaha untuk mengatasi akibat-akibat buruk dari dua kecenderungan, yaitu (1) spesialisasi ilmu yang berlebihlebihan, (2) penonjolan ranah intelektual kognitif atau ranah psikomotor saja. General Education berusaha menyajikan pendidikan yang akan membina para mahasiswa menjadi manusia-manusia yang memiliki kepribadian yang terpadu. ${ }^{20}$

Latar belakang lahirnya pendidikan umum secara lebih jelas dikemukakan oleh McConeel yang menyatakan,

General education was a reaction against over specialization, against imbalance between the pursuit of special interest and the attainment of the broader cultivation that the liberally educated man was traditionally expected to possess. It was a reaction too, against the fragmentation of the curriculum and the disunity in the student's educational experience that were the inevitable concomitants of the vast increase in specialized knowledge ... general education was and is a reaction against formalism in liberal education. $^{21}$

Uraian tersebut menjelaskan empat hal yang melatarbelakangi lahirnya general education, yaitu: 1) sebagai suatu reaksi terhadap spesialisasi keilmuan yang berlebihan, 2) sebagai reaksi terhadap ketidakseimbangan antara penguasaan minat-minat khusus dengan pemerolehan peradaban yang lebih luas, 3) sebagai reaksi terhadap pengkotak-kotakan kurikulum dan perpecahan pengalaman belajar mahasiswa, dan 4) sebagai reaksi terhadap formalisme dalam pendidikan liberal.

Harvard Committe mengemukakan alasan yang melatarbelakangi semakin meningkatnya perhatian terhadap general education dengan pernyataan sebagai berikut,

Why has this concern (about general education) become so strong in late years? Among many reasons three stand out: the staggering expansion of knowledge produced largely by specialist and certainly conducing to it; the concurrent and hardly less staggering 
growth of our educational system with its maze of least, the evergrowing complexity of society it self. ${ }^{22}$

Pernyataan di atas menjelaskan bahwa lahirnya general education bukan semata-mata karena meningkatnya spesialisasi ilmu pengetahuan, melainkan juga karena pertumbuhan dan perkembangan kehidupan masyarakat.

Selain itu, secara lebih lengkap, P. L. Dressel dan M. F. Lorimer, mengemukakan latar belakang dari lahirnya general education yang pada intinya adalah, 1) daya pendorong general education secara langsung dapat ditemukan pada perkembangan (ekspansi), diferensiasi yang progresif dan sistematis dari pengetahuan ke dalam suatu peningkatan jumlah disiplin dan spesialisasi, 2) pertumbuhan penduduk, industrialisasi, dan perkembangan dalam komunikasi dan transportasi yang telah menimbulkan pekerjaan dan profesi baru yang menyertai kebutuhan bagi spesialisasi, 3) peningkatan jumlah mahasiswa yang tidak dapat dihindarkan meningkatkan rentang kemampuan akademik, minat, dan latar belakang sosial budaya yang harus dilayani oleh perguruan tinggi, 4) basic education masih menjurus, relatif sempit, content oriented, dan terutama didesain untuk mepersiapkan mahasiswa menempuh pelajaran berikutnya. Interrelasi mata pelajaran dengan masalah kemanusiaan diremehkan dan diserahkan kepada mahasiswa itu sendiri untuk menemukannya. ${ }^{23}$

Dari apa yang telah ditemukan di atas ,maka memang tampak spesialisasi dan pengkotakkotakan ilmu pengetahuan ataupun kurikulum dalam suatu sistem pendidikan akan terlalu menonjolkan disiplin keilmuan dan cenderung bersifat intelektualisme. Pendidikan pun pada akhirnya cenderung mendesak pertimbangan-pertimbangan kemanusiaan dan tidak relevan lagi dengan kebutuhan, nilai-nilai, serta masalah-masalah kemanusiaan yang fundamental. Pada tinjauan lain, pendidikan yang terpesialisasi secara berlebihan akan memilah-milah pengalaman belajar mahasiswa, membuat kepribadian mereka tidak utuh dan menjauhkan mereka dari kehidupan nyata di masyarakat.

Definisi general education yang lebih jelas dikemukakan oleh Alberty and Alberty yang sekaligus membedakan pendidikan umum (general education) dengan pendidikan spesialisasi (specialized education). Mereka mengemukakan definisi sebagai berikut,

General education is that part of the program which is required of all students at a given level on the ground that it is essential to development of the common values, attitudes, undersatanding, and skills needed by all for common democratic citizenship. Specialized education is that part of the program which is designed to meet the special needs and interest of individuals or groups. This part of the program includes both non vocational apportunities (Alberty and Alberty, 1965: 203). ${ }^{24}$

Definisi dari Alberty dan Alberty ini dapat dijelaskan bahwa dalam kurikulum sekolah menengah ada dua program atau menurut istilah Alberty, ada pengalaman kurikuler (curricular 
experience), yang berbeda. Ada pengalaman kurikuler atau program yang diarahkan terutama pada perkembangan kewarganegaraan yang umum, yang meliputi cita-cita umum, nilai-nilai, sikap-sikap, dan pengertian. Pengalaman kurikuler seperti itu disebut general education.

Dalam kaitan dengan pengertian general education, Philip H. Phenix mengemukakan secara singkat bahwa, "... general educationis the process of engendering essential meaning." ${ }^{25}$ la mengemukakan pernyataan tersebut dengan dasar bahwa setiap manusia perlu memahami makna yang esensial yang diperlukan bagi pembentukan dirinya sebagai manusia yang memiliki kepribadin yang terpadu dan menyeluruh (whole person). Dalam pandangan Phenix, ada enam bidang makna fundamental yang mesti dimilikioleh setaip manusia dan mesti diupayakan tertanam melalui pendidikan. Keenam bidang makna (realms of meaning) tersebut adalah symbolics, empirics, esthetics, synnoethics, ethics, dan synoptics. ${ }^{26}$

Keenam bidang makna fundamental tersebut, merupakan makna esensial yang diperlukan bagi pembinaan kepribadian setiap manusia yang terpadu dan menyeluruh, menurut Phenix, merupakan sesuatu yang mesti diberikan melalui pendidikan umum (general education).

Dengan demikin, beberapa aspek dan karakteristik khas general education yang antara lain diambil dari beberapa definisi di atas, yaitu, 1) general education merupakan program kurikulum sekolah yang diberikan kepada/ diikuti oleh semua siswa pada semua jenis dan jenjang sekolah dan perguruan tinggi, 2) general education diarahkan untuk mengembangkan seluruh kepribadian siswa, 3) general education bertanggung jawab pada perkembangan emosional, sosial, moral, dan juga intelektual dengan cara yang terintegrasi, 4) general education merupakan program yang mengembangkan nilai, sikap, pengertian, dan keterampilan umum yang diperlukan oleh semua warga negara yang demokratis, 5) general education merupakan proses untuk melahirkan (menanamkan) makna esensial bagi kehidupan manusia, yang meliputi makna simbolik, empirik, estetik, etik, senoetik, dan sinoptik.

Apabila kita melihat secara kurikuler, yang disebut dengan general education di Perguruan Tinggi (secara struktural disebut dengan MKU atau MKDU atau MKWU), terdiri dari matakuliahmatakuliah yang secara disiplin ilmu berlainan, yaitu Pendidikan Agama, Pendidikan Kewarganegaraan, IImu Sosial dan Budaya Dasar, Pendidikan Bahasa Indonesia, Pendidikan Bahasa Inggris, Pendidikan Olah Raga, dan Filsafat IImu (pada sebagian Perguruan Tinggi), yang kesemuanya mengandung unsur pembinaan kepribadian dan penanaman nilai, olah hati, dan olah rasa. $^{27}$

Dalam kajian akademis, general education belum memiliki konsep yang jelas, baik secara substansial maupun fungsional. Meskipun demikian, para ahli pendidikan satu persepsi bahwa general education adalah pendidikan untuk semua orang (education for all). Oleh karena itu, para 


\section{Fastabiq: Jurnal Studi Islam}

ISSN 2723-0228

Volume 1 Nomor 2 Nopember 2020

pakar pendidikan terus menerus mengembangkan konsep Pendidikan Umum ini, dalam konteks kebutuhan masyarakat dan zamannya.

Endang Soemantri melihat general education haruslah berfungsi sebagai teras bagi pendidikan, dan menjadi komplemen bagi pendidikan kejuruan, dengan tujuan mengembangkan: (1) Kecerdasan kritis yang dapat digunakan dalam berbagai lapangan kehidupan; (2) Pembinaan karakter \& kewargaan; (3) Kesatuan jiwa \& keutuhan intelektual; (4) Keseimbangan hidup dalam ekonomi dan sosial; dan (5) Kesejahteraan hidup dalam lingkup keluarga dan warga masyarakat yang bertanggungjawab. ${ }^{28}$

Oleh sebab itu, menurut Soemantri, minimal terdapat tiga rumusan kajian sebagai muatan dari general education, antara lain: 1) Humaniora, yaitu sastra \& seni yang membentuk kepribadian agar menjadi manusia bijak. 2) Studi dan kajian manusia, yaitu kajian-kajian sosial, etika, ilmu politik, ekonomi, psikologi, sosiologi dan antropologi. 3) IImu Pengetahuan Alam, yaitu fisika, kimia, geologi, astronomi dan biologi yang bertugas mengembangkan sikap dan cara kerja ilmiah. ${ }^{29}$

Dengan demikian, general education memuat pendidikan tentang nilai-nilai budaya, nilai-nilai sosial, dan nilai-nilai ilmiah akademik. Inilah pokok-pokok terpenting dari general education dengan berbagai disiplin ilmu yang dilibatkan dalam proses pendidikannya.

Djahiri memiliki pandangan yang lain, bahwa tugas general education adalah merekayasa peserta didik ke arah: 1) Penemuan dan perwujudan jati diri manusia, masyarakat dan bangsa, 2) Pembinaan, pengembangan kehidupan diri dan lingkungan. Dengan kedua penjelasan tersebut, kita mendapatkan arti memanusiawikan manusia, dengan empat target yang harus diperoleh oleh setiap peserta didik, yaitu 1) Humanizing, memanusiawikan individu, sosial, dan lingkungan. 2) Civilizing of human being, yaitu memiliki kecerdasan dan berbudaya, memiliki tanggung- jawab terhadap Tuhan dan masyarakat. 3) Empowering, memberdayakan sehingga berguna bagi kemanusiaan. 4) Socializing (memiliki kepekaan sosial yang tinggi), sehingga menjadi individu-individu yang berfungsi baik sebagai warga masyarakat. ${ }^{30}$

Keseluruhan target pendidikan dalam Pendidikan Umum berada pada ranah afektif, yang bersifat unik, psikologis, changeable, dan developmental. Pendidikan afektif merupakan pendidikan yang diarahkan pada qalbu atau nurani atau hati terdalam, berupa penanaman nilai-nilai moral, untuk membangun moralitas pada individu. Nilai-nilai kebaikan yang ditanamkan ke dalam hati setiap individu melalui pendidikan afektual, dapat bersumber dari: 1) Agama, untuk mengklarikasi nilai-nilai sehingga personalizing sebagai a conscious man. 2) Budaya, yaitu kebiasaan suatu masyarakat. 3) Negara, seperti nilai-nilai Pancasila dan peraturan/ hukum positif. 4) IImu-Pengetahuan, teori dan dalil-dalil keilmuan. ${ }^{31}$

\section{Pendidikan Agama dalam General Education}




\section{Fastabiq: Jurnal Studi Islam}

ISSN 2723-0228

Volume 1 Nomor 2 Nopember 2020

Ahmad Tafsir sebagai pakar pendidikan agama Islam, memiliki pandangan bahwa, general education harus ditujukan untuk "membina insan agar mampu mengendalikan diri." Kemampuan pengendalian diri sepenuhnya hanya memungkinkan bisa terjadi apabila manusia terikat kuat pada nilai-nilai yang diajarkan Tuhan, karena keterhubungan (habl) dengan Tuhan akan menjadikan perbuatan baik manusia memiliki makna secara ruhaniah, dan kebahagiaan batiniah sebagai balasan atau keringanan dari pengurbanan yang menjadi penderitaannya sebagai efek dari perlawanan terhadap dorongan hawa nafsunya. Nilai-nilai kebaikan yang berasal dari Allah sebagai khaliq, yang disebut dengan akhlak, akan lebih mapan dan tepat apabila dibandingkan dengan nilai-nilai moral insaniah, yang disebut etika, karena nilai-nilai dalam akhlak tidak banyak berubah, bersifat baku, meskipun dalam penerapannya sangat fleksibel dan bisa menyesuaikan. Inilah, menurut Tafsir, inti penting pendidikan agama dalam general education, yaitu membangkitkan komitmen peserta didik pada nilai-nilai yang diajarkan Allah. ${ }^{32}$

Adapun menurut Sofyan Sauri, pendidikan agama dalam general education adalah untuk memasukkan cita-cita luhur pendidikan nasional yang dengan lugas menyatakan tujuan pendidikan dengan rumusan, "Membina manusia yang beriman dan bertakwa, berkepribadian dan berbudi pekerti luhur .... (UUSPN 20, th. 2003). ${ }^{33}$

Dalam konten tujuan pendidikan semacam ini, adanya pendidikan agama menjadi persyaratan inti, karena dengan nilai-nilai agamalah kepribadian yang beriman dan bertakwa, yang memiliki komitmen pada nilai-nilai kebaikan yang luhur dapat dibina dan dikembangkan. Penanaman nilai-nilai moral ilahiah melalui agama akan lebih baik dan berjalan semestinya, karena agama mengharuskan eksistensi kekuatan ghaib (iman), sebagai tempat bergantung, jalinan hubungan yang baik dengan al-Khalik, yang dapat menimbulkan efek emosional: pada diri yang manifest secara positif dalam perasaan takut, cinta, dan harap. Pengakuan akan kemahasucian dan sakralitas nilai juga akan memperkuat komitmen spiritual bagi penganutnya.

Selain itu, agama juga berperan positif bagi perkembangan individu dalam menempuh jalan kehidupannya, karena agama memberikan arah tujuan yang jelas dalam kehidupan, memberikan kemampuan menyesuaikan secara adaptif dengan jati dirinya, dapat menjadi hiasan batin, memberi harapan dan dorongan bagi jiwa, memberikan ketenangan pada jiwa pemiliknya yang tekun, serta memberikan jawaban yang memuaskan terhadap setiap pertanyaan ke"mengapa"an dari dunia dan kehidupan ini.

Menurut pendidikan agama yang religius, yang menekankan pada penanaman nilai-nilai agama, unsur dosen atau pendidik sebagai figur pribadi-pribadi yang religius yang merefleksikan nilai-nilai agama yang diajarkannya, tidak dapat diabaikan dan merupakan suatu keharusan, yang tidak bisa ditawar-tawar. Pendidik agama harus merupakan model (role model) dari nilai-nilai agama itu sendiri yang tampil dalam ekspresi pemikiran dan perbuatan secara sesungguhnya dan 
sebenarnya, sehingga dapat dijadikan figur tempat siswa binaan mengidentifikasi diri. Karena itu, pendidik agama dalam proses pendidikan harus menampilkan diri sebagai media pendidikan. Tampak di sini, pendidikan agama harus ditampilkan dan diajarkan oleh pendidik yang menganut agama yang diajarkannya, dan sama dengan agama yang dianut oleh peserta didik/ mahasiswa. Hal ini agar terjadi resonansi antara tiga unsur dalam proses pendidikan agama, yaitu guru (dosen), (maha)siswa, dan ajaran agama. Sebaliknya, apabila pendidikan agama diajarkan oleh guru yang tidak seagama dengan (maha)siswa, atau siswa diberi pendidikan agama dengan nilai-nilai yang bukan agama yang dianutnya, maka akan terjadi disonansi dalam proses pendidikan. Disonansi dalam proses pendidikan akan membangun jiwa yang labil dan pribadi yang terbelah (split personality) yang dalam dirinya penuh kontradiksi. Dengan demikian, pendidikan agama yang dilaksanakannya akan sia-sia dan tidak mencapai sasaran pendidikan secara efektif, bahkan destruktif bagi perkembangan pribadi anak didik. ${ }^{34}$

\section{SIMPULAN}

Substansi Mata Kuliah Wajib Umum Pendidikan Agama merupakan rangkaian proses pembinaan untuk mempertemukan fitrah keberagamaan seseorang dengan nilai-nilai agama untuk meningkatkan religiusitasnya. Mata kuliah wajib umum pendidikan agama sebagai general education yang bersifat ilahiah, pada tataran konseptual haruslah merupakan pendidikan yang religius, tidak hanya sebatas pengalihan pengetahuan (transfer knowledge) tentang ajaran-ajaran agama, yaitu pendidikan yang tidak sekedar menyentuh aspek kognitif, tetapi pendidikan yang dapat menembus hati dan kesadaran batin peserta didik.

Mata Kuliah Wajib Umum Pendidikan Agama memerlukan pendekatan khusus dan pengelolaan yang serius dalam proses belajar-mengajarnya, baik menyangkut materi, metodologi, pendidik, lingkungan, dan iklim belajarnya serta kualitas dan kuantitas pertemuan yang terjadi antara pendidik dan peserta didik. Pendidik dalam pendidikan agama bukan sekedar penyampai bahan ajar dan pengelola proses belajar mengajar semata, tetapi ia harus tampil sebagai model (role model) dari nilai nilai agama itu sendiri untuk ditiru oleh siswa. 


\section{ENDNOTE}

\footnotetext{
${ }^{1}$ Riyanto. (2009). Model Penyelenggaraan Mata Kuliah Umum di Universitas Pendidikan Indonesia. Bandung: UPI dan Ditjen Dikti Depdiknas. Hal. 1

${ }^{2}$ Hanafi. (2016). Transformasi Kurikulum Mata Kuliah Pendidikan Agama Islam di Perguruan Tinggi Umum: Dari Paradigma Normatif-Doktriner Menuju Paradigma Historis-Kontekstual. Jurnal Pendidikan dan Pembelajaran, Volume 23, Nomor 1, April 2016. Hal. 27

${ }^{3}$ Riyanto. (2009). Model.... Hal. 2

4 Direktorat Jenderal Pendidikan Tinggi. (1983). Surat Keputusan Direktorat Jenderal Pendidikan Tinggi Nomor 32/DJ/Kep/1983. Jakarta. Deparatemen Pendidikan dan Kebuayaan. Hal. 37.

${ }^{5}$ Hanafi. (2016). Transformasi .... Hal. 28

${ }^{6}$ Surat Keputusan Direktorat Jenderal Pendidikan Tinggi Nomor 43/ DIKTI/Kep/2006 tentang Ramburambu Pelaksanaan Kelompok Matakuliah Pengembangan Kepribadian di Perguruan Tinggi

${ }^{7}$ Hanafi. (2016). Transformasi .... Hal. 29

${ }^{8}$ Undang-Undang Nomor 12 Tahun 2012 tentang Pendidikan Tinggi

${ }^{9}$ Nurdin. (2017). Model Kelembagaan Lembaga Pengelola Mata Kuliah Wajib Umum di Perguruan Tinggi. Bandung: Forum MKWUSI dan UPI. Hal. 1

${ }^{10}$ Nurdin. (2017). Model Kelembagaan Lembaga Pengelola Mata Kuliah Wajib Umum di Perguruan Tinggi. Bandung: Forum MKWUSI dan UPI. Hal. 2

${ }^{11}$ Berdasarkan Pasal 35 ayat (3) Undang-Undang RI Nomor 12 Tahun 2012.

12 Joachim. (1984). IImu Perbandingan Agama. (Terj.). Jakarta: Rajawali. Hal. 59.

${ }_{14}^{13}$ Muthahhari (1984). Manusia dan Agama. (Terj.). Bandung: Mizan. Hal. 43-44

14 Soelaeman. (1988). Suatu Telaah tentang Manusia-Religi-Pendidikan. Jakarta: Proyek
} Pengembangan LPTK Dirjen Dikti. Hal. 43-44.

${ }^{15}$ Said. (1989). Ilmu Pendidikan. Bandung: Alumni. Hal. 19

${ }^{16}$ Dahlan. (1988). Posisi Bimbingan dan Penyuluhan Pendidikan dalam Kerangka IImu Pendidikan. Bandung: IKIP Bandung. Hal. 15.

${ }_{17}$ Trueblood, D. (1972). Filsafat Agama. Terj. Rasjidi. Jakarta: Bulan Bintang. Hal. 7.

18 Sarbaini. (2015). Cakrawala Pendidikan Umum: Perspfektif Pendidikan Berbasis Pembinaan Karakter. Universitas Lambung Mangkurat: UPT MKU. Hal.

${ }^{19}$ Harris. (1968). Encyclopedia of Educational Research. New York: The Mac Millan Company. Hal. 570

${ }^{20}$ Maftuh. (2009). Bunga Rampai Pendidikan Umum dan Pendidikan Nilai. Bandung: Program Studi Pendidikan Umum/ Nilai SPs UPI. Hal. 2

${ }^{21}$ Henry. (1952). General Education, The Fifty Years Book. Chicago: The University of Chicago Press. Hal. 2

${ }^{22}$ Harvard Committe. (1950). General Education in Free Society. Harvard University. Hal. 4

${ }^{23}$ Harris. (1968). Encyclopedia... Hal. 571

${ }^{24}$ Alberty, H. B., dan Alberty, E. J. (1965) Reorganizing the High School Curriculum. Third Ediction. New York: The Mac Millan Company. Hal. 203

${ }^{25}$ Phenix. (1964). The Realms of Meaning. New York: The Mac Millan Company. Hal. 5

${ }^{26}$ Phenix. (1964). The Realms .... Hal. 6

27 Sarbaini. (2015). Cakrawala Pendidikan Umum: Perspfektif Pendidikan Berbasis Pembinaan Karakter. Universitas Lambung Mangkurat: UPT MKU. Hal. 44

${ }^{28}$ Sumantri. (2009). Pendidikan Umum. Bandung: Prodi Pendidikan Umum SPs UPI. Hal. 10

29 Ibid Hal. 11

${ }^{30}$ Djahiri. (1996). Menelusuri Dunia Afektif. Bandung: Lab PMPKn IKIP Bandung. Hal. 15

${ }^{31}$ Ibid Hal. 16

32 Tafsir, A. (2008). Strategi Meningkatkan Mutu Pendidikan Agama Islam. Bandung: Maestro. Hal. 16-17.

${ }^{33}$ Sauri. (2010). Meretas Pendidikan Nilai. Bandung: Arfino Raya. Hal. 25 
${ }^{34}$ Rizal. (2015). Hakekat Pendidikan Agama dalam Konteks Pendidikan Umum. Editor, Sarbaini. Universitas Lambung Mangkurat: UPT MKU. Hal. 47

\section{REFERENSI}

Alberty, H. B., dan Alberty, E. J. (1965) Reorganizing the High School Curriculum. Third Ediction. New York: The Mac Millan Company.

Dahlan. M. D. (1988). Posisi Bimbingan dan Penyuluhan Pendidikan dalam Kerangka IImu Pendidikan. Bandung: IKIP Bandung.

Direktorat Jenderal Pendidikan Tinggi. (1983). Surat Keputusan Direktorat Jenderal Pendidikan Tinggi Nomor 32/DJ/Kep/1983. Jakarta. Deparatemen Pendidikan dan Kebuayaan. Hal. 37.

Djahiri, K. (1996). Menelusuri Dunia Afektif. Bandung: Lab PMPKn IKIP Bandung.

Hanafi. (2016). Transformasi Kurikulum Mata Kuliah Pendidikan Agama Islam di Perguruan Tinggi Umum: Dari Paradigma Normatif-Doktriner Menuju Paradigma Historis-Kontekstual. Jurnal Pendidikan dan Pembelajaran, Volume 23, Nomor 1, April 2016.

Harris. (1968). Encyclopedia of Educational Research. New York: The Mac Millan Company.

Harvard Committe. (1950). General Education in Free Society. Harvard University.

Henry, N. B. (1952). General Education, The Fifty Years Book. Chicago: The University of Chicago Press.

Joachim. (1984). Ilmu Perbandingan Agama. (Terj.). Jakarta: Rajawali.

Maftuh, B. (2009). Bunga Rampai Pendidikan Umum dan Pendidikan Nilai. Bandung: Program Studi Pendidikan Umum/ Nilai SPs UPI.

Muthahhari, M. (1984). Manusia dan Agama. (Terj.). Bandung: Mizan.

Nurdin, E. S. (2017). Model Kelembagaan Lembaga Pengelola Mata Kuliah Wajib Umum di Perguruan Tinggi. Bandung: Forum MKWUSI dan UPI.

Phenix, P. H. (1964). The Realms of Meaning. New York: The Mac Millan Company.

Riyanto, A. (2009). Model Penyelenggaraan Mata Kuliah Umum di Universitas Pendidikan Indonesia. Bandung: UPI dan Ditjen Dikti Depdiknas.

Rizal, A. S. (2015). Hakekat Pendidikan Agama dalam Konteks Pendidikan Umum. Editor, Sarbaini. Universitas Lambung Mangkurat: UPT MKU.

Said. (1989). IImu Pendidikan. Bandung: Alumni.

Sarbaini. (2015). Cakrawala Pendidikan Umum: Perspfektif Pendidikan Berbasis Pembinaan Karakter. Universitas Lambung Mangkurat: UPT MKU.

Sauri, S. (2010). Meretas Pendidikan Nilai. Bandung: Arfino Raya.

Soelaeman, M. I. (1988). Suatu Telaah tentang Manusia-Religi-Pendidikan. Jakarta: Proyek Pengembangan LPTK Dirjen Dikti.

Sumantri, E. (2009). Pendidikan Umum. Bandung: Prodi Pendidikan Umum SPs UPI.

Surat Keputusan Direktorat Jenderal Pendidikan Tinggi Nomor 43/ DIKTI/Kep/2006 tentang Ramburambu Pelaksanaan Kelompok Matakuliah Pengembangan Kepribadian di Perguruan Tinggi

Tafsir, A. (2008). Strategi Meningkatkan Mutu Pendidikan Agama Islam. Bandung: Maestro.

Trueblood, D. (1972). Filsafat Agama. Terj. Rasjidi. Jakarta: Bulan Bintang.

Undang-Undang Nomor 12 Tahun 2012 tentang Pendidikan Tinggi 